\title{
Hepatitis B and hepatitis delta virus infection in South America
}

\author{
J R Torres $\mathbf{R}$
}

\begin{abstract}
About 100000 cases of acute hepatitis B virus (HBV) infection occur annually in South America. The overall prevalence of HBV infection in low risk populations ranges from $6 \cdot 7 \%$ to $41 \%$, while hepatitis $B$ surface antigen (HBsAg) rates range from $0.4 \%$ to $13 \%$. In high endemicity aboriginal or rural populations, perinatal transmission may play a major part in the spread of HBV. In urban populations, however, horizontal transmission, probably by sexual contact, is the predominant mode of spread, with higher rates of HBV positivity in lower socioeconomic groups. High risk populations such as health care workers and haemodialysis patients show higher rates of $\mathrm{HBV}$ infection than comparable populations elsewhere. The risk of posttransfusion hepatitis $B$ remains high in some areas. Concomitant HBV infection may accelerate the chronic liver disease seen in decompensated hepatosplenic schistosomiasis. In the north, the prevalence of hepatitis delta virus (HDV) infection ranks among the highest in the world. In the south, the problem appears negligible although it is increasing within high risk urban communities. HDV superinfection has been the cause of large outbreaks of fulminant hepatitis. The cost of comprehensive or mass vaccination programmes remains unaffordable for most South American countries. Less expensive alternatives such as low dose intradermal schedules of immunisation have been used with success in selected adult subjects.

(Gut 1996; 38 (suppl 2): S48-S55)
\end{abstract}

Keywords: hepatitis B, hepatitis delta, South America, epidemiology, control.

Viral hepatitis remains an important cause of morbidity and mortality in many Latin American countries, where hepatitis A virus (HAV), hepatitis B virus (HBV), hepatitis C virus (HCV), hepatitis delta virus (HDV) and, to a lesser degree, hepatitis $\mathrm{E}$ virus, have all been reported as aetiological agents of both major regional outbreaks and isolated cases. ${ }^{1-14}$ Among these, HBV, HCV, and HDV are the key agents responsible for chronic infection and liver disease.

In common with other developing regions of the world with high rates of viral hepatitis, most South American countries display socioeconomic conditions that favour the occurrence of hepatitis $B$ and other related infections. Such conditions are characterised, among other factors, by a deteriorating public health and educational infrastructure, overcrowding of populations crammed into a few large cities, resulting from uncontrolled internal and external influxes of population, as well as persistent and extreme poverty. ${ }^{4571014-16}$

While it is certain that both HBV and HDV infections are highly prevalent in South America, pronounced regional differences in infection and carrier rates do exist, not only among different nations within the area but also - because of racial, geographical, socioeconomic, and other related factors - within individual countries. Thus, in terms of morbidity and mortality, a complex regional mosaic of epidemiological patterns and pathologies emerges.

\section{Data limitations}

Information on $\mathrm{HBV}$ prevalence in different areas of South America remains partial and scarce, at best. Most available data are inherently biased as they originate from blood bank reports, and blood donors are often selected from healthy adult populations. Furthermore, blood banks that perform routine HBV serological screening are mostly located in urban settings, and important differences in testing methodology exist.

Although National Hepatitis Committees have been established to facilitate the accumulation of valuable local data, only limited information exists from any single country with regard to $\mathrm{HBV}$ prevalence according to race, age, socioeconomic level or urban/rural status. As most cases of HDV infection occur precisely in rather remote locations, such as the Amazon Basin, where the prevalence of $\mathrm{HBV}$ infection is highest, epidemiological information is especially hard to collect. Moreover, the true prevalence of HDV can be difficult to estimate because it increases the severity of chronic liver disease and is also found more frequently in people with chronic $\mathrm{HBV}$ liver disease than in asymptomatic HBV carriers. Therefore, to clarify the level of endemicity and the predominant regional patterns of HDV spread, more reliable figures are required on HDV prevalence, both in known HBV carriers and in those people with chronic liver disease. ${ }^{7131718}$

The shortcomings of analysing limited epidemiological data are illustrated by two recent surveys of different Peruvian towns. ${ }^{4} 10$ One such survey showed that the prevalence of antibodies to hepatitis B surface antigen (antiHBs) in coastal towns was very similar to that reported in the main cities, reaching a high of $16 \%{ }^{410}$ In contrast, towns located closest to
Correspondence to: Dr J R Torres R, Sociedad Medica Clínica Santa Sofia, PO Box 14-9073, Coral Gables, F1 
jungle areas showed the highest prevalence of anti-HBs of approximately $86 \% .{ }^{410}$ The authors suggested two possible factors to explain these findings: firstly, the proximity of the latter two towns to the Amazonic region; secondly, the probability that, in those areas, $\mathrm{HBV}$ infection is acquired at an early age. ${ }^{10}$

In Huanta (Ayacucho), an Andean city located 2400 metres above sea level, 36 healthy native residents and 100 acute hepatitis patients were evaluated as part of the same study. ${ }^{4}$ The prevalences of hepatitis B surface antigen (HBsAg) and antibodies to hepatitis B core antigen (anti-HBc) were found to be $5.5 \%$ and $30.5 \%$, respectively, among residents, and $21 \%$ and $53 \%$ among patients. Not a single case of HDV infection was reported. In contrast, a similar study carried out among 143 healthy students selected randomly from four schools in the same city only two years later showed a much higher prevalence of $\mathrm{HBsAg}$ $(16 \%)$, and anti-HBc $(84 \cdot 8 \%)$, as well as markers of previous HDV infection $(17.9 \%$ with anti-HDV antibodies). ${ }^{19}$

\section{SEROLOGICAL ASSAYS}

Some South American countries currently manufacture their own diagnostic kits for either HBV or HDV. As a result, the serological assays used in each study may vary, further complicating the interpretation of available data. The high cost of diagnostic tests prevents precise identification of the specific virus involved in each reported case, which also affects the quality of surveillance records.

Newly developed serological assays remain out of reach for most South American countries, and are not expected to be routinely introduced in the near future. They include the new micro ELISA techniques for detection of HBV pre-S1 protein and anti-pre-S2, HBVDNA hybridisation techniques, polymerase chain reaction (PCR) with oligonucleotides specific for certain regions of the HBV genome, HDV antigen (HDAg) determination by immunoblotting, and HDV-RNA detection by spot hybridisation.

The many shortcomings in available data further hamper the assessment of the actual impact of $\mathrm{HBV}$ and HDV infections on the occurrence of chronic hepatitis and primary liver carcinoma, as well as their interaction with alcoholic and post-transfusion hepatitis in the region.

\section{Hepatitis B epidemiology}

PREVALENCE

Data accumulated from blood banks suggest that the total number of HBV carriers in Latin America may exceed six million, with the Amazon Basin (including large areas of Brazil, and parts of Colombia, Venezuela, and Peru) representing a reservoir of high endemicity. ${ }^{6} 13$ HBV infection alone accounts for many cases of acute hepatitis and, ultimately, a considerable number of cases of chronic hepatitis, cirrhosis, and hepatocellular carcinoma (HCC). ${ }^{5-7} 13$
HBV continues to spread throughout South America with very variable frequencies between one region and another. ${ }^{7} 13$ Available surveillance data on partially classified hepatitis cases have shown morbidity rates that range from 25 to 150 cases per 100000 population per year. ${ }^{920}$ A significant proportion of such cases - mostly those seen in the adult population - can be attributed to HBV infection. Accumulated data also suggest that $\mathrm{HBV}$ is the cause of $25-67 \%$ of all cases of chronic hepatitis in Latin America and is also probably responsible for $10-70 \%$ of all cases of primary liver carcinoma. ${ }^{91320}$

\section{Acute hepatitis $B$}

$\mathrm{HBV}$ as a cause of acute hepatitis has only been investigated in a few countries, where it has been shown to be the causative agent in up to $50 \%$ of patients screened. 279121321 In general, it has been estimated that 140000 to 400000 new cases of acute hepatitis $B$ may be occurring annually in the entire Latin American region - two thirds of them in South America alone - including 440 to 1000 cases of fulminant hepatitis. ${ }^{6913} 162022-26$ Higher rates of fulminant hepatitis are seen in areas where concurrent $\mathrm{HBV}$ and $\mathrm{HDV}$ infections are common. ${ }^{13} 1622-26$

\section{Chronic hepatitis $B$}

Currently available information on the epidemiology of chronic hepatitis B infection in the region is largely derived from seroprevalence studies in blood donors. According to such studies, the seroprevalence of $\mathrm{HBsAg}$ ranges from $0.4 \%$ in some areas of Chile up to $13 \%$ in northern Brazil, demonstrating a wide spectrum of HBsAg prevalence, not only within the region, but also between different populations of a particular geographical area (Table I). ${ }^{2679-1113202127-29}$ However, it should be emphasised that calculations of HBV seroprevalence based only on HBsAg determination in blood donors probably underestimate the actual level of HBV infection in a particular country. Larger population screening studies incorporating additional HBV serological markers, such as anti-HBc and anti-HBs, will provide a more accurate picture. ${ }^{79101718202129}$ Data such as these are available for only half of all South American nations, as shown in Table II, but serve to demonstrate the importance of this disease as a serious public health problem regionally.

Precise numbers of chronic HBV carriers in Latin America are hard to obtain. However, most of the analyses estimate that between 6.6 and 12 million Latin Americans - more than $65 \%$ of them living in South America alone are infected with HBV. 56913202830

\section{Sequelae of chronic hepatitis $B$}

Additional longitudinal studies are required to clarify the actual impact of chronic HBV infection on the occurrence of longterm sequelae such as chronic active hepatitis and liver 
TABLE I Geographical distribution of $\mathrm{HBs} A g$ in South America according to seroprevalence level $2679-1120-212729$

\begin{tabular}{lll}
\hline Low prevalence & Intermediate prevalence & High prevalence \\
\hline$<2 \%(0 \cdot 3-2 \%)$ & $2-10 \%(2 \cdot 2-8 \%)$ & $\begin{array}{c}>10 \% \\
\text { Amazon Basin (Brazil, Colombia, } \\
\text { Perú, Venezuela) }\end{array}$ \\
& $\begin{array}{c}\text { Brazil (north), Colombia, } \\
\text { Perú, Suriname }\end{array}$ & \\
$\begin{array}{c}\text { Argentina, Bolivia, Brazil } \\
\text { (south), Chile, Ecuador, } \\
\text { Paraguay, Uruguay }\end{array}$ & & \\
\hline
\end{tabular}

cirrhosis in South America. Nevertheless, both complications are known to occur extensively in the Amazon Basin, as well as in other areas of high HBV endemicity. ${ }^{6} 713$ 31-33

Based on the lowest annual estimate of 140000 acute HBV infections in Latin America, it can be anticipated that there will be at least 8000 to 15000 new chronic carriers of HBV, more than 4000 cases of chronic active hepatitis and a variable number of cases of cirrhosis every year. It has been estimated that up to 60000 cases of cirrhosis and 3000 cases of liver carcinoma annually could be related to HBV infection. 679132030

Contrary to reports from hyperendemic areas in other parts of the world, serum $\alpha$ fetoprotein values do not seem to be a reliable indicator of the risk of HCC or severe chronic liver disease due to $\mathrm{HBV}$ or $\mathrm{HCV}$ infection in some South American countries. ${ }^{34}$ Serum values of $\alpha$ fetoprotein remain either normal or only slightly increased in most urban patients with confirmed chronic liver disease, in accordance with the lower enzymatic inflammatory activity and negative $\mathrm{HBeAg}$ pattern already reported in the region. ${ }^{1835}$ However, among 232 Amerindians of all ages from an isolated Venezuelan Yanomami community, with overall positivity rates of $7 \cdot 8 \%$ for $\mathrm{HBsAg}$ and $12 \%$ for anti-HCV (RIBA), abnormally increased serum $\alpha$ fetoprotein values were seen in up to $12.4 \%$ of the 121 subjects over 30 years of age. Within this age subgroup, $7 \%$ were positive for HBsAg and $16 \%$ for anti-HCV (J R Torres, C Botto, unpublished data).

\section{ROUTES OF TRANSMISSION}

\section{Perinatal transmission}

Most HBV seroprevalence studies carried out in pregnant women have failed to show clearly a perinatal pattern of $\mathrm{HBV}$ transmission in South American urban areas. HBsAg positivity rates in these women have been found to resemble those reported in low risk populations and blood donors. ${ }^{5132029}$ Recent seroepidemiological surveys in Caracas have shown that, as in the general population, low income pregnant women exhibit higher anti-HBc and HBsAg positivity rates compared with women from higher income brackets. ${ }^{18} 2736$ Moreover, in contrast with findings in Asiatic populations, hepatitis $\mathrm{B}$ e antigen ( $\mathrm{HBeAg}$ ) positivity is seen only infrequently in $\mathrm{HBsAg}$ carrier women and $\mathrm{HBV}-\mathrm{DNA}$ is also negative as determined by nested-PCR techniques, suggesting a low rate of perinatal transmission in this population. ${ }^{182736}$ Nevertheless, in 1985, it was estimated that HBV induced liver deaths among Latin American babies could be expected to reach over 33000 per 13.5 million births. ${ }^{679}$ It is likely that, in areas of high HBV endemicity such as the Amazon Basin, the perinatal route may play a major part in the propagation of the disease. Initial studies in isolated Yanomamo communities of the Upper Orinoco Basin, for example, have shown that $75 \%$ of all $\mathrm{HBsAg}$ carriers - all of whom are also $\mathrm{HBeAg}$ positive - are women of childbearing age. ${ }^{12} 13$ Furthermore, the prevalence of anti-HBc among children aged 1-4 years reached an astounding $66 \%$, with an $\mathrm{HBsAg}$ prevalence of $33 \% .^{12} 13$

\section{Post-transfusion hepatitis $B$}

There is a paucity of data on the risk of posttransfusion hepatitis in Latin America. However, a prospective longterm follow up study of 147 Venezuelan patients who received transfusions of either whole blood or blood components from volunteer donors that had been screened for $\mathrm{HBsAg}$, anti-HBc, ALT, and anti-HCV, showed development of posttransfusion hepatitis in eight cases $(6 \cdot 1 \%){ }^{37}$ Five were associated with $\mathrm{HBV}$ infection and only three with $\mathrm{HCV}$ infection. It seems, therefore, that the risk of post-transfusion hepatitis $B$ is comparable to or even greater than that for post-transfusion non-A, non-B/type $C$ hepatitis in some south American countries with a moderate to high prevalence of $\mathrm{HBsAg}$ positivity. ${ }^{37}$

\section{Health care workers}

As reported extensively worldwide, health care workers are at increased risk of acquiring HBV infection through percutaneous contact. ${ }^{38}$ In South America, anti-HBc positivity rates in health care workers seem to be even higher than those in health professionals at comparable risk in developed countries, but similar to those in local low risk populations (for example, $20 \%$ in Brazil, Peru, and Venezuela, and $15 \%$ in Argentina). ${ }^{7} 13$ 39-43 These indirect data provide confirmation of the intermediate level of HBV endemicity in many South

TABLE II Seroepidemiology of HBV infection in South America, including surveys in low risk populations ${ }^{2} 679-1120212729$

\begin{tabular}{|c|c|c|}
\hline Countries & $H B s A g$ & $\begin{array}{l}\text { Positive } H B V \text { serological } \\
\text { markers }(H B s A g, \text { anti-HBc, } \\
\text { or anti-HBs })^{\star}\end{array}$ \\
\hline Argentina & $1 \cdot 1$ & $18 \cdot 6$ \\
\hline Bolivia & $1 \cdot 6$ & - \\
\hline Brazil & $3 \cdot 4$ & $31 \cdot 5$ \\
\hline South & 1.0 & - \\
\hline Middle West & $1 \cdot 0$ & - \\
\hline South East & $2 \cdot 0$ & $34 \cdot 0$ \\
\hline North East & $2 \cdot 5$ & - \\
\hline North & $8 \cdot 0$ & - \\
\hline Colombia & $2 \cdot 8$ & $29 \cdot 3$ \\
\hline Chile & 0.5 & $6 \cdot 7$ \\
\hline Ecuador & $2 \cdot 0$ & $35 \cdot 3$ \\
\hline Paraguay & $0 \cdot 9$ & - \\
\hline Perú & $0 \cdot 9$ & $28 \cdot 5$ \\
\hline Suriname & $1 \cdot 4$ & $41 \cdot 0$ \\
\hline Uruguay & $0 \cdot 9$ & - \\
\hline Venezuela & $2 \cdot 0$ & $16 \cdot 5$ \\
\hline
\end{tabular}

^Methods: immunodiffusion, counterimmunoelectrophoresis, reverse passive haemagglutination, radioimmunoassay, enzyme linked immunoassay. 
American urban areas. They also support both the existence of special epidemiological conditions that maintain the prevalence of HBV infection in health care workers, and the potential benefit of mass $\mathrm{HBV}$ vaccination programmes. $^{41}$

\section{High risk populations}

Higher frequencies of HBV infection have been reported in high risk South American populations than in comparable populations from other parts of the world. ${ }^{16} 2744-46$ These include polytransfused patients, haemodialysis patients, homosexuals, and prostitutes. In haemodialysis patients, combined infection with both HBV and HCV seems to be prevalent in some regions. In one Venezuelan study, 50 of $123(41 \%)$ anti-HCV positive haemodialysis patients were positive for at least one HBV serological marker, while only $27 \%$ of 191 anti-HCV negative patients were also HBV positive. ${ }^{47}$ The occurrence of $\mathrm{HBV} /$ $\mathrm{HCV}$ coinfection was not only found to correlate directly with both the number of transfusions and the time on haemodialysis, but was also identified as a major cause of increased serum ALT values. ${ }^{47}$ Other regional studies carried out in haemodialysis and renal transplant patients have shown anti-HBc/anti-HBs positivity rates of over $40 \% .{ }^{444647}$ In a more recent survey of 227 patients from four metropolitan haemodialysis units in Caracas, $51 \%$ were found to be positive for anti$\mathrm{HBc}, 22 \%$ for $\mathrm{HBsAg}, 0.4 \%$ for anti-HDV, and $67 \%$ for anti-HCV. ${ }^{48}$ Importantly, HCVRNA was shown not only in $90 \%$ of the 154 anti-HCV positive patients but also in up to $30 \%$ of anti-HCV negative patients, possibly indicating a high rate of recently acquired infections. Overall, no less than $62 \cdot 5 \%$ of patients showed evidence of either chronic or acute $\mathrm{HCV}$ infection. ${ }^{48}$ In addition, a sharp increase in the rate of $\mathrm{HBV}$ infection among intravenous drug abusers in Latin American urban communities has recently been identified, thus worsening an already precarious situation. 314950

\section{Schistosomiasis and HBV}

Schistosomiasis and HBV infection coexist in large coastal areas of Brazil and Venezuela. Although there is no evidence to date that either disease represents a risk factor for the other, epidemiological and clinical data indicate that concomitant HBV infection does play a part in the acceleration of the chronic liver disease seen in decompensated hepatosplenic schistosomiasis (HSS). In fact, chronic HBV infection has been shown to be prevalent in patients with HSS, but not in those with the hepatointestinal form of the disease. ${ }^{51}$ More recently, an appreciably increased rate of HBsAg positivity, with evidence of active viral replication (HBV-DNA positivity), has been seen in HSS patients with decompensated liver disease compared with that in patients with compensated disease or hepatointestinal schistosomiasis, suggesting that $\mathrm{HBV}$ is a major pathogenic factor in progression to more severe forms of HSS. ${ }^{52}$

\section{Summary}

The results of many seroepidemiological surveys suggest that, in hyperendemic regions, the pool of chronic HBV carriers probably arises from perinatal or early childhood infection. On the other hand, studies performed in urban populations with lower HBV carrier rates suggest that sexual transmission is the predominant mode of HBV spread in those areas, and that $\mathrm{HBV}$ positive subjects are more often adults than children. ${ }^{2} 1320$ Furthermore, some countries have reported a higher prevalence of $\mathrm{HBV}$ infection in the poorest urban areas or in lower socioeconomic population segments. ${ }^{1} 1317282953$ Generally, the results of the various retrospective and prospective investigations carried out to date suggest that horizontal transmission probably represents the major mode of HBV spread in the main Latin American cities. Undoubtedly, the reported prevalence of $\mathrm{HBV}$ in urban areas and in healthy populations is lower than that seen in aborigine populations. ${ }^{2} 791213151920212753$

\section{Hepatitis delta epidemiology}

As HDV is dependent on HBV for its replication, it can only infect those people who are simultaneously infected with HBV (coinfection) or who are already carriers of HBV (super infection). As a result, the distribution and prevalence of $\mathrm{HDV}$ in Latin America tend to parallel those of $\mathrm{HBV}$, particularly in populations with overt factors predisposing to parenteral or sexual routes of transmission, such as some Amerindian communities. ${ }^{4-6912131554}$ However, as in other less developed tropical areas of the world, the epidemiology of HDV infection in South America is marked by great contrasts. Thus, HDV may cause widespread outbreaks of both fulminant and chronic hepatitis in the northern part of the continent, whereas it is virtually absent in other areas with a similar or even higher HBV endemicity. 5121326 54-56

Based on current worldwide estimates, at least 300000 people in the region $(5 \%$ of the estimated six million HBsAg carriers) are infected with HDV and most are suffering from significant liver disease. ${ }^{1316}$ In general, the occurrence of $\mathrm{HDV}$ infection is lowest in temperate zones of Latin America, with a prevalence gradient that increases in equatorial tropical and subtropical zones. In fact, certain populations in northern regions of South America have served as a high endemicity model of HDV transmission. ${ }^{57912-141657}$ Moreover, HDV superinfection has been incriminated as the aetiological agent in a number of outbreaks of severe hepatitis, including Santa Marta hepatitis in western Colombia, large numbers of cases among Yucpa and Yanomamo Indians in Venezuela, and Labrea Fever and other related fulminant liver conditions devastating the Upper Amazon Basin of Brazil and Peru, and the Upper Orinoco basin of Venezuela and Colombia. ${ }^{3} 591213$ 55-58 
GEOGRAPHICAL VARIATIONS

With regard to HDV infection, South America can be divided in two well defined areas. In the south, the problem appears negligible, particularly in Chile, Uruguay and, to a lesser degree, Argentina. In the north - particularly in the Amazon Basin, which is beset by poor sanitary conditions - the prevalence of HDV ranks among the highest in the world. ${ }^{12} 1315315556$ Nevertheless, recent studies in countries with a low overall prevalence of HDV infection indicate that the penetration of HDV within high risk communities, such as intravenous drug abusers and homosexuals or bisexuals, is higher. ${ }^{626}$ Indeed, the rate of HDV infection among drug abusers from large South American cities such as Buenos Aires jumped fourfold to sixfold in a period of only three years, representing an increasingly important source of infection. ${ }^{6}$

An unexpectedly high rate of $\mathrm{HBsAg}$ $(30 \cdot 6 \%)$ and $\mathrm{HDV}$ infection $(39 \cdot 7 \%)$ has been found among isolated Yanomami in Venezuela. ${ }^{1213}$ Most (75\%) of the HBsAg positive cases were women of reproductive age and, remarkably, all HBV carriers had concomitant HDV infection. ${ }^{12} 13$ Perinatal transmission seemed to be the predominant route of $\mathrm{HBV}$ infection, while $\mathrm{HDV}$ infection occurred later in life. Interestingly, retrospective serological and epidemiological evidence suggests that the onset of a longlasting outbreak of severe acute and chronic liver disease affecting the same villages might have coincided with the introduction of HDV in a population with a high pre-existing level of HBV infection. ${ }^{12} 13$

Recent studies in central and western Brazilian populations highly endemic for HBV infection also showed a very high prevalence of HDV infection. ${ }^{26}$ Anti-HDV was found in $20-30 \%$ of $\mathrm{HBsAg}$ carriers and acute hepatitis cases, in $30-50 \%$ of fulminant hepatitis B cases, and in $85-90 \%$ of chronic active hepatitis and cirrhosis patients. ${ }^{26}$

In large urban areas of South America, few cases of HDV infection are currently reported other than among intravenous drug abusers. Indeed, serological surveys in asymptomatic HBV carriers in Chile have proved consistently negative for HDV, while in Rio de Janeiro (Brazil), HDV was found among only $0.5 \%$ of 200 HBV carriers. $^{626}$ Furthermore, seroepidemiological studies in adult Venezuelans at high risk for HBV or HIV infection, or both, proved negative for HDV markers. ${ }^{42} 45$

The high rate of HBsAg positivity found in areas of the Amazon and Orinoco Basins resembles that seen among some Asian and African populations, where carrier rates of between 10 and $20 \%$ are not unusual. ${ }^{9}$ It is plausible that the Amazon and Orinoco Basins offer an ecological system especially favourable for the transmission of HDV. Possible influences include genetic differences, specific cultural habits, potential animal reservoirs, nutritional factors, a high prevalence of skin lesions, or even differences in virulence of the prevalent HDV strains. ${ }^{135960}$
FULMINANT HEPATITIS

Investigations among Yucpa Indians of western Venezuela reported for the first time in an open community the importance of HDV superinfection as the cause of large outbreaks of fulminant hepatitis in populations with a high pre-existing HBV endemicity. 5558 A high percentage $(70 \%)$ of $\mathrm{HBV}$ carriers with HDV superinfection showed persistently increased ALT values, reaching at least four times the upper limit of normal in $25 \%$ of cases. Significantly enlarged spleens were seen in about half of all simultaneously infected people. Necropsy specimens obtained during the same epidemic exhibited a histopathological picture consisting of microvacuolar fatty infiltration of hepatocytes ('morula cells') and various degrees of eosinophilic necrosis and inflammation. The clinical, epidemiological, and histopathological similarities between this outbreak and two other distinct entities recognised for over 40 years (Labrea Fever in northern Brazil, and Santa Marta Hepatitis in western Colombia) rapidly became evident. A retrospective review of a large number of viscerotomy specimens collected in Colombia since 1936 showed the same typical histopathological pattern in at least four distinct areas of the country. ${ }^{1}$ Moreover, HDAg was eventually identified by immunoperoxidase staining in the nuclei of morula cells in up to $70 \%$ of the samples assayed. ${ }^{1}$ Similar findings have been noted in necropsy material collected from Yucpa Indians with severe or fulminant hepatitis and from patients with Labrea hepatitis. ${ }^{25} 58$

Labrea hepatitis presents clinically with intense vomiting, right upper quadrant pain, fever, jaundice, hepatic coma, and death within a few days of the onset of symptoms. Children, adolescents and young adults are mainly affected. ${ }^{22}$ Although Labrea hepatitis has generally been described as being the result of HDV superinfections in $\mathrm{HBV}$ carriers, ${ }^{5}$ it has also recently been reported as being related to $\mathrm{HAV}$ and $\mathrm{HCV}$ infections. ${ }^{22}$

\section{CONCLUSIONS}

Various aspects of the epidemiology of HDV infection in Latin America remain to be defined. However, while further epidemiological, clinical, and pathological studies are certainly needed, mass prevention programmes through hepatitis B immunisation of susceptible children are a clear priority for some hyperendemic areas.

\section{Diagnosis and prevention of $\mathrm{HBV}$ \\ infection in South America}

Serological diagnosis of $\mathrm{HBV}$ is a complex process due to the multiple viral markers present during the different phases of the disease - that is, high and low viraemic phases, the acute period, the convalescence and resolution stages, and progression to chronic infection. ${ }^{356162}$ 
DONOR SCREENING

The selection of a diagnostic and of an appropriate HBV screening system for blood banks in South America must depend largely upon the availability (or lack) of expensive imported reagents. As a result, the serological follow up of $\mathrm{HBV}$ infections and the incorporation of more reliable assays into blood bank procedures incur considerable expenses and are difficult to set up. Thus, first and second generation tests and pooling of blood for HBsAg screening are still the standard in some countries. ${ }^{720}$

In some regions, successful efforts have been made to develop and manufacture locally more reliable assays for the detection of $\mathrm{HBsAg}$ and anti-HBc. However, standard testing for anti$\mathrm{HBc}$ as a surrogate marker for post-transfusion non-A, non-B, non-C hepatitis ${ }^{63}$ has been implemented in only a few local blood banks. As the prevalence of anti-HBc in South American blood donors and in low risk general populations is relatively high, and HBV-DNA may be documented in the serum of many such subjects, ${ }^{13} 35616364$ routine anti-HBc screening in urban as well as rural blood banks may prove highly beneficial.

Technological transfer and further local development of non-ELISA or RIA based reagents are among the recommendations proposed by different national and international health organisations to improve the situation. Meanwhile, investigation of pre-S determinants and establishment of molecular techniques such as slot-blotting, dot-blotting, and PCR have already been incorporated into blood bank procedures in some countries, which are now able to provide complete HBV screening. ${ }^{136164-66}$

\section{DIAGNOSIS}

According to various reports, the clinical features of acute and chronic HBV infection in South America are no different to those reported in other parts of the world. ${ }^{761}$ Thus, for example, there is a 4:1 preponderance of male over female patients in both acute and chronic cases, and a predominance of chronic disease during the third and fourth decades of life. ${ }^{761}$ It has been reported that anti-HBe positive patients - generally considered to be in a low or non-viraemic phase of the disease represent the majority of chronic $\mathrm{HBsAg}$ carriers in Venezuela. ${ }^{61}$ However, around one third of these $\mathrm{HBsAg}$ positive/anti-HBe positive carriers test positive for HBV-DNA in serum, indicating ongoing viral replication and active hepatitis. ${ }^{61} 64$ In both types of carriers, infections appear to be due to the wild type virus. Most $\mathrm{HBsAg}$ carriers and anti-HBc positive subjects also have antibodies to pre-S2, thus confirming a true exposure to HBV. The possibility that some carriers might be infected with HBV mutants remains to be further investigated. ${ }^{6167}$ In this respect, although preliminary studies in Brazilian anti-HBe positive patients with chronic hepatitis $B$ did not reveal serum HBV-DNA positivity by dot-blot hybridisation, more recent assessments using PCR in 49 patients confirmed the occurrence of active viraemia in most cases. ${ }^{66}$ A plausible explanation for these findings is the occurrence of precore mutant infections.

\section{IMMUNISATION}

The high risk of morbidity and mortality associated with HBV infections has prompted the delineation and establishment of $\mathrm{HBV}$ control strategies in endemic areas. ${ }^{68-70}$ Approaches outlined by the World Health Organisation Programme for Control of Viral Hepatitis include HBsAg screening of pregnant women, vaccination of newborns of $\mathrm{HBV}$ carrier mothers, immunisation of health care personnel, and immunisation of other high risk groups. ${ }^{49} 7172$

The introduction of standard $\mathrm{HBsAg}$ screening for pregnant women ${ }^{7374}$ seems feasible only in those countries where HBsAg assay kits are currently manufactured or in favoured socioeconomic segments of the population. Routine universal $\mathrm{HBsAg}$ screening in pregnant women, therefore, has not yet been incorporated in South America. Moreover, as most mothers are anti-HBe positive, mass immunisation (whenever possible) of all children seems a more cost effective strategy.

The establishment of pilot HBV vaccination programmes is the most widely adopted strategy in South American countries. 67203071 Priority has been given to the implementation of vaccination of newborns and children in hyperendemic areas, including the whole Amazonic territory. ${ }^{75}$ The largest of these immunisation programmes has been accomplished in Brazil. ${ }^{30}$ Since 1989,11 rural and urban areas, with an estimated population of 95011 children aged 0 to 10 years, have been targeted for protection. So far, more than 60000 children $(66 \cdot 6 \%)$ have completed the course of all three doses of the HBV vaccine, as part of the Expanded Programme on Immunisation (EPI).$^{30} 75$ In addition, a further 52 municipalities located in the Brazilian Amazon have been incorporated to the HBV vaccine programme. ${ }^{75}$ Other hyperendemic areas, such as Sierra de Perija and the Alto Orinoco Basin in Venezuela, or Sierra de Santa Marta in Colombia, where outbreaks of HBV and $\mathrm{HDV}$ infections with high death rates have been well documented, have initiated comprehensive vaccination programmes that include children and susceptible adult populations.

Little information exists on the serological response to vaccine among Amerindians from hyperendemic areas in South America. In one study, however, $226 \mathrm{HBsAg}$ negative/anti-HBs negative volunteers from Jivaro and Arawak communities in the Peruvian Amazon were vaccinated with a recombinant DNA vaccine. ${ }^{76}$ The overall seroconversion rate to antiHBs was $84.9 \%$, with $73.5 \%$ of people developing anti-HBs serum values higher than $10 \mathrm{mIU} / \mathrm{ml}$. Importantly, it was observed that significantly better seroprotection rates and serum concentrations of anti-HBs were achieved in previously anti-HBc negative people. ${ }^{76}$ Therefore, when vaccinating in hyperendemic Amerindian communities, it 
might be beneficial to evaluate their serological response at the end of the vaccination.

There is no comprehensive national policy for vaccination of health care workers anywhere in the area but immunisation of personnel at risk is consistently performed in many health centres and in some medical and dental schools. Pilot vaccination projects for health care personnel are also being conducted in many countries, ${ }^{30} 40$ and cost-benefit studies evaluating the impact of either selective or mass vaccination for hospital and patient-care unit staff have clearly shown the economic advantages of both strategies. ${ }^{39} 4177$ However, it has been estimated that the total financial burden derived from both the direct and indirect costs of $\mathrm{HBV}$ infection and the vaccination programmes is too high for most Latin American countries, partly because of the high price of commercially available $\mathrm{HBV}$ vaccines. ${ }^{41}$

Low dose immunisation schedules, using either plasma derived or yeast derived vaccines given intradermally, have been tried successfully in Brazilian health care workers ${ }^{78} 79$ and in Venezuelan medical students. ${ }^{80}$ Seroconversion rates and levels of anti-HBs achieved after low intradermal doses were comparable to those obtained with standard intramuscular doses. Moreover, $91.4 \%$ of vaccinated health workers showed anti-HBs levels over 11 times the cut off level (that is, the level considered a good antibody response) 36 months later. ${ }^{79}$

Local vaccine production or access to cheaper sources of HBV vaccines have been proposed as alternative solutions. ${ }^{20}$ In this respect, a genetically engineered Cuban HBV vaccine is currently being commercialised successfully in several South American countries. ${ }^{81}$ Ensuring that the market price of $\mathrm{HBV}$ vaccines is proportional to the particular economic capabilities of each country in the region is essential if mass control programmes are to be carried out effectively.

\section{SUMMARY}

In summary, strategies for global control of HBV in Latin America are similar to those recommended by the WHO worldwide. ${ }^{497182}$ Universal HBsAg screening of blood and blood products, availability of suitable $\mathrm{HBV}$ marker reagents, and an extensive infant HBV immunisation programme integrated into the EPI are three desirable goals. Meanwhile, overall control of $\mathrm{HBV}$ infection and its sequelae in South America is urgently awaited.

1 Buitrago B, Popper H, Hadler SC, et al. Specific histologic features of Santa Marta hepatitis: a severe form of hepatitis delta-virus infection in northern South America. Hepatology 1986; 6: 1285-91.

2 Bensabath G, Hadler SC, Pereira Soares MC, et al. Epidemiologic and serologic studies of acute viral hepatitis in Brazil's Amazon Basin. Bull Pan Am Health Organ 1987; 21: 16-27.

3 Centres for Disease Control. Enterically transmitted non-A non-B hepatitis - Mexico. MMWR 1987; 36: 241-3.

4 Sjogren MH, Colichon A. Hepatitis B and Delta hepatitis infection in Peru. Progr Clin Biol Res 1991; 364: 97-104.

Bensabath G, Hadler SC, Pereira MC, et al. Hepatitis delta virus infection and Labrea hepatitis. Prevalence and role in fulminant hepatitis in the Amazon Basin. $\mathcal{F} A M A$ 1987; 258: 479-83.
6 Fay O. Hepatitis B in Latin America: epidemiological pattern and eradication strategy. The Latin American
Regional Study Group. Vaccine 1990; 8 (suppl): S100-12.

7 Hadler SC, Fay OH, Pinheiro F, et al. La hepatitis en las Américas: informe del Grupo Colaborador de la OPS. Bol Oficina Sanit Panam 1987; 103: 185-209.

8 Hadler SC. Global impact of Hepatitis A Virus infection changing patterns. In: Hollinger FB, Lemon SM, Margolis HS, eds. Viral hepatitis and liver disease. Baltimore: Williams \& Wilkins, 1991: 14.

9 Hepatitis virica en la región [Editorial]. Bol Oficina Sanit Panam 1986; 100: 330-442.

10 Mendez M, Arce M, Kruger $\mathrm{H}$, et al. Prevalencia de marcadores serológicos de hepatitis vírica en diversos grupos de población del Perú. Bol Oficina Sanit Panam 1989; 106: 127-32.

11 Nath N, Mazzur S, Frang C, et al. Prevalencia de los anticuerpos contra el virus A de la Hepatitis (VHA) en donantes de sangre de 13 paises y territorios del Hemisferio Occidental. Bol Oficina Sanit Panam 1981; 90: 425-32.

12 Torres JR, Mondolfi A. Protracted outbreak of severe delta hepatitis: experience in an isolated Amerindian population of the Upper Orinoco Basin. Rev Infect Dis 1991; 13: 52-5.

13 Torres JR, Machado I. Special aspects of hepatitis B infection in Latin America. Infect Dis Clin North Am 1994; 8: tion in 26.

14 Vetencourt R, Suarez A, Boada J, et al. Estudio clínico y epidemiológico de 256 casos de Hepatitis Viral Aguda. GEN 1984; 38: 1-11.

15 Valladares G, Galarza J, Espinoza J, et al. Determinación de marcadores serológicos del virus de la Hepatitis $B$ en areas de alto riesgo del Hospital Central Fuerza Area del Perú. Rev Gastroenterol Peru 1989; 9: 13-9.

16 Velasco M, de la Fuente C. Estudio del antígeno de superficie de la Hepatitis B en 489 prostitutas de Santiago. Rev Med Chile 1983; 111: 461-2.

17 Machado I, Monzón M, Fernandez R, et al. Hepatitis B virus: a public health problem in Venezuela. Bull Pan Am Health Organ 1985; 19: 176-81.

18 Machado I. A propósito de políticas Nacionales de Salud en relación con hepatitis viral. Informes presentados en Mayo 1985 y Septiembre 1986 ante la Organización Mayo 1985 y Septiembre 1986 ante la Organización Panamerica

19 Cabezas C, Gotuzzo E, Escamilla J, Phillips Y. Prevalencia de marcadores serológicos de hepatitis viral A, B y delta en escolares aparentemente sanos de Huanta (Perú). Rev Gastroenterol Peru 1994; 14: 123-34.

20 Reports of PAHO Ad Hoc Committee on Viral Hepatitis. 1985-1990

21 Mazzur S, Nath N, Fang C, et al. Distribución de marcadores de virus de hepatitis B (VHB) en la sangre de donadores de 13 paises del hemisferio occidental: actas del taller Latinoamericano de la Cruz Roja sobre hepatitis del taller Latinoamericano de la Cruz Roja sob

22 Fonseca JCF, Ferreira LCL, da Silva ALP, et al. Hepatite fulminante e febre negra de Labrea: estudo de 5 casos procedentes de Codajas, Amazonas, Brasil. Rev Soc Brasi Med Trop 1983; 16: 144-7.

23 Fonseca JCF, Gayotto LCC, Ferreira LCL, et al. Labrea hepatitis - hepatitis B and delta antigen expression in live tissue: report of three autopsy cases. Rev Inst Med Trop Sao Paulo 1985; 27: 224-7.

24 Fonseca JCF, Simonetti SRR, Schatzmayr HG, et al. Prevalence of infection with hepatitis delta virus (HDV) among carriers of hepatitis B surface antigen in Amazonas State, Brazil. Trans $R$ Soc Trop Med Hyg 1988; 82: State, Braz $469-71$.

25 Fonseca JCF, Ferreira LCL, Brasil LM, et al. Fulminant Labrea hepatitis - the role of hepatitis A (HAV), B (HBV), C (HCV), and D (HDV) infection. Preliminary report. Rev Inst Med Trop Sao Paulo 1992; 34: 609-12.

26 Gayotto LC. Hepatitis delta in South America and especially in the Amazon region. Prog Clin Biol Res 1991; 364: 123-5.

27 Machado IV, Carvajal J, Mondolfi A, et al. Seroepidemiological differences of HBV infection between urban areas and Amerindian population in Venezuela. In: Zuckerman AJ, ed. Viral hepatitis and liver disease. New York: Alan R Liss, 1988: 174-6.

28 Hepatitis B vaccination: weekly epidemiological record. Relev Epidemiologique Hebdomaire 1988; 63: 13 .

29 Machado I, Marquez M, Bianco N. Virus de hepatitis B encuesta inmuno-epidemiológica en diferentes cortes de población venezolana. GEN 1983; 37: 237.

30 Fay O, Pinheiro F, Tanno $\mathrm{H}$, et al. Programmea de vacunación contra HVB en América Latina [Abstract] Gastroenterologia y Hepatologia 1992; 15: 307.

31 Figueroa R, Phillips IA, Barham B, et al. Marcadores virales de hepatitis $B$ y C en población peruana con enfermedad hepática crónica [Abstract]. GEN 1992; 46: 263 .

32 Viola L, Fernandez JL, Morgante P. Carcinoma hepatocelular: relación con cirrosis, virus $\mathrm{B}$, alcohol y virus $\mathrm{C}$. Gastroenterología y hepatología [Abstract]. GEN 1992; 15: 341 .

33 Zumaeta E, Figueroa BR, Navarrete J. Cancer primario del higado en el Hospital Edgardo Rebagliatti Martins del IPSS. (1965-1991). Lima-Perú [Abstract]. GEN 1992; 46: 259.

34 Sejias LF, Montilla I, Zabaleta M, et al. Determinación de lfa feto proteina en pacientes infectados con virus B y C. Comunicación preliminar. GEN 1993; 47: 65-9.

35 Machado IV. Inmunobiologia del virus de la hepatitis $B$ GEN 1991; 45: 315-22. 
36 Pujol F, Rodriguez Y, Martinez N, et al. Viral hepatitis serological markers among pregnant women in Caracas, Venezuela: implication for perinatal transmission of hepatitis B and C. GEN 1994; 48: 25-8.

37 León G, Sore A, Celis S, Semprúm O, Acosta V, Gómez O. Hepatitis postransfusional. Estudio preliminar. Sangre 1991; 36: 93-7.

38 Maynard JE, Kane MA, Alter MJ, et al. Control of hepatitis $B$ by immunization: global perspectives. In: Zuckerman $\mathrm{B}$ by immunization: global perspectives. In: Zuckerman Aj, ed. Viral hepati

39 Choc de Zenalda B, Manterola AC, Diaz Lestrem M, et al. Prevalencia del anticuerpo contra el antígeno central del virus de la hepatitis $B$ (anti-HBc) en personal hospitalario de Buenos Aires. Bol Oficina Sanit Panam 1990; 108: $16-9$.

40 Deville J, Llanos A, Campos M, et al. Factores de riesgo para infección por virus de Hepatitis $\mathrm{B}$ en personal hospitalario. Rev Gastroenterol Perú 1989; : 24-30.

41 Fernandez R, Rivero D, Echeverría B, et al. Costo-beneficio de la vacunación contra la hepatitis $B$ en trabajadores de hospitales de Venezuela. Bol Oficina Sanit Panam 1991; 111: $16-23$.

42 Machado I, Marcano NB, Rosales A, et al. Riesgo de exposición ocupacional al virus de la hepatitis $\mathrm{B}$ en personal de Salud venezolano. Estudio multicéntrico. $G E N$ 1990; 44: 1-8.

43 Vildosola $\mathrm{H}$, Colichón A, Bardolas $\mathrm{T}$, et al. Prevalencia de marcadores serológicos de hepatitis $\mathrm{B}$ en personal de salud y administrativo de un Hospital General de la Selva del Perú. Rev Gastroenterol Perú 1989; 9: 77-81.

44 Castilho MC, Melik AMM, Brasil LM, et al. Infección por los virus de las hepatitis B (VHB) y C (VHC) en hemodializados, Manaus, Brasil [Abstract]. GEN 1992; 4

45 Machado IV, Deibis L Zabaleta ME et al Assessment of delta virus infection in Venezuelan high-risk population for

46 Frider B, Castaño G, Sookoian S, et al. Infección for HBV y $\mathrm{HCV}$ en transplantados renales [Abstract]. GEN 1992; 46: 238

47 Muller GY, Zabaleta ME, Arminio A, et al. Risk factors for dialysis associated hepatitis $\mathrm{C}$ in Venezuela. Kidney Int 1992; 41: 1055-8.

48 Ponce J, Lema M, Capriles F, et al. Alta prevalencia de marcadores de hepatitis virales en hemodialisados de Caracas [Abstract]. Bol Venez Infectolog 1994; 4: 38.

49 Progress in the control of viral hepatitis: memorandum from a WHO meeting. Bull World Health Org 1988; 66: 443-50.

50 Farfán G, Vidal J, Phillips I, et al. Marcadores serológicos de hepatitis viral B en pacientes drogadictos del Hospital hepatitis viral B en pacientes drogadictos del Hospital 95-101.

51 Lyra LG. Esquistossomose mansonica e o virus B: do inicio ao estado atual. Moderna Hepatologia Especial 1983; 2: $1-7$

52 Leila M, Pereira LM, Melo CV, et al. Hepatitis B virus infection in schistosomiasis mansoni. F Med Virol 1994; 42: 203-6.

53 Colichon A, Siogren M, Galvez J, et al. Hepatitis B and delta hepatitis in habitants of Peruvian Amazon Basin. In Zuckerman AJ, ed. Viral hepatitis and liver disease. New York: Alan R Liss, 1988: 425.

54 Rizzetto M, Ponzetto A, Forzani I. Epidemiology of hepatitis delta virus: overview. Progr Clin Biol Res 1991; 364: $1-20$.

55 Hadler SC, Monzon M, Bensabath G, et al. Epidemiology of hepatitis delta virus infection in less developed countries. Progr Clin Biol Res 1991; 364: 21-31.

56 Rizzetto M, Ponzetto A, Forzani I. Hepatitis delta virus as a global health problem. Vaccine 1990; 8 (suppl): S10-4.

57 Villanueva A, Fraser P, García R, et al. Fulminant hepatitis in the Sierra Nevada: a superinfection of delta virus on hepatitis B virus. In: Zuckerman AJ, ed. Viral hepatitis and liver disease. New York: Alan R Liss, 1988: 415

58 Popper H, Thung SN, Gerber MA, et al. Histologic studies of severe delta agent infection in Venezuelan Indians. Hepatology 1983; 3: 906-12.

59 Faure P, Parana R, Vitvitski L, et al. Further evidence of immunological and genomic differences between the prototype HDV strain and a strain presumably associated with Spongiocytic Fulminant Hepatitis (SFH) in man and woodchuck. Progr Clin Biol Res 1991; 364: 45.

60 Roisman F, Castello A, Salamone M, et al. Linfotropismo del virus del la hepatitis $B$, analisis de la expresion de los antígenos víricos [Abstract]. Gastroenterología $y$ Hepatologia 1992; 15: 243.

61 Zabaleta ME, Toro FI, Ruiz ME, et al. Assessment of former and newly developed HBV assays in a third world setting. 7 Med Virol 1992; 38: 245

62 Hoofnagle JH. Chronic hepatitis B. N Engl f Med 1990; 323: 337-9.

63 Koziol DE, Holland PV, Alling DW, et al. Antibody to hepatitis $\mathrm{B}$ core antigen as a paradoxical marker for nonA non-B hepatitis agents in donated blood. Ann Intern Med 1986; 104: 488-95.

64 Machado Y, Deibis L, Risquez E, et al. Abordaje inmunoclínico, molecular e inmunopatológico de la hepatitis crónica viral. Consideraciones terapeúticas. GEN 1994; 48: $124-32$.

65 Morales M, Nazabal M, Ibarguen C. Detection of HBVDNA in serum by PCR in the course of acute hepatitis [Abstract]. GEN 1992; 46: 262.

66 Pinho JR, Santos CA, Gonzalez C, et al. Detection of hepatitis $\mathrm{B}$ virus DNA by the polymerase chain reaction in anti-HBe positive chronic hepatitis B patients. Rev Inst Med Trop Sao Paulo 1993; 35: 515-20.

67 Fonseca JCF, Castilho MC, Carvalho JAB, et al. Ausencia de infección por el virus de la hepatitis B (VHB) mutante Brasil: informe preliminar [Abstract]. GEN 1992; 46: Brasil:

68 Blumberg B. Feasibility of controlling or eradicating the hepatitis B virus. Am $\mathcal{Y}$ Med 1998; 87 (suppl 3A): 3-7A

69 Garrison MW, Barker DE. Therapeutic advances in the prevention of hepatitis B: yeast-derived recombinant hepatitis B vaccines. DICP, Ann Pharmacother 1991; 25: 617-22.

70 Clements CJ, Kane M, Hu DJ, et al. La Vacuna contra la hepatitis B: un neuvo frente contra las enfermedades pandémicas. Foro Mundial de la Salud 1990; 11: 165-71.

71 Kane MA, Ghendon Y, Lambert P-H. Hepatitis B in 1990 Where are we and where are we going? The WHO Programmeme for control of viral hepatitis. In: Hollinger FB, Lemon SM, Margolis HS, eds. Viral hepatitis and liver disease. Baltimore: Williams \& Wilkins, 1991: 706.

72 Palmer-Beasley R. Hepatitis B immunization strategies. World Health Organization. Expanded Programme of Immunization. Document WHO/EPI/GEN/88-1988; 5:

73 Arévalo JA, Washington AE. Cost-effectiveness of prenatal screening and immunization for hepatitis $\mathrm{B}$ virus. $\mathfrak{f} A M A$ 1988; 259: 365-9.

74 Centers for Disease Control. Prevention of perinatal transmission of hepatitis B virus: prenatal screening of all pregmission of hepatitis B virus: prenatal screening of all preg37: $341-4$.

75 Fonseca JC, Brasil LM, Braga WSM, et al. Informe actual sobre el progammea de vacunación contra el VHB en el estado de Amazonas, Brasil [Abstract]. GEN 1992; 46: 242

76 Colichon A, Vildosa H, Sjogren M, Cantella R, Safary A. Respuesta serológica a una vacuna DNA recombinante en nativos residentes de dos areas hiperendémicas a hepatitis B en la Amazonia Peruana. Rev Gastroenterol Perú 1993; 13: $78-84$.

77 Lahaye D, Strauss F, Baleaux C, et al. Cost-benefit analysis of hepatitis-B vaccination. Lancet 1987; ii: 441-3.

78 Carrilho FJ, Queiroz ML, Silva LC, et al. Active immunization against hepatitis B virus with low doses of plasma-
tarrilho FJ, Queiroz $\mathrm{LL}$, Silva LC, et al. Active immunizaderived vaccine by intradermal route. Rev Inst Med Trop Sao Paulo 1989; 31: 91-3.

79 Carrilho FJ, Queiroz ML, Fonseca LE, et al. Active immunization against HBV with low doses of plasma-derived vaccine by intradermal route. Anti-HBs response after three years follow-up. Rev Inst Med Trop Sao Paulo 1991; 33: $167-8$.

80 Torres JR, Marquez M, Gonzalez A, et al. Eficacia comparativa de las vías intradérmica e intramuscular en la inmunización activa contra la hepatitis $B$ con una vacuna nizacion activa contra la hepatitis $B$ con una vacuna
recombinante. Resultados preliminares. GEN 1993; 47: recombina.

81 Gonzalez Griego M, Ramirez V, Muzlo V, et al. Vacuna cubana anti-hepatitis $\mathbf{B}$ de antigeno de superficie viral ADN recombinante [Abstract]. GEN 1992; 46: 257.

82 Boletin del Grupo Internacional de Trabajo en Inmunización contra la hepatitis B y del Programa para la Tecnología Apropiada de la Salud (PATH). Perspectivas sobre la Hepatitis 1992; 2: 1. 